\title{
Scabraside D Extracted from Holothuria scabra Induces Apoptosis and Inhibits Growth of Human Cholangiocarcinoma Xenografts in Mice
}

\author{
Kanjana Assawasuparerk ${ }^{1,2,3}$, Rapeepun Vanichviriyakit ${ }^{1,2}$, Charoonroj \\ Chotwiwatthanakun ${ }^{4}$, Saksit Nobsathian ${ }^{4}$, Thanakorn Rawangchue ${ }^{5}$, Boonsirm \\ Wittayachumnankul ${ }^{1,2,6 *}$
}

\begin{abstract}
Scabraside D, a sulfated triterpene glycoside extract from sea cucumber Holothulia scabra, shows various biological activities, but effects on human cholangiocarcinoma cells have not previously been reported. In the present study, we investigated the activity of scabraside $D$ against human cholangiocarcinoma (HuCCA) both in vitro and for tumor growth inhibition in vivo using a xenograft model in nude mice. Scabraside D (12.5-100 $\mu \mathrm{g} / \mathrm{mL}$ ) significantly decreased the viability and the migration of the HuCCA cells in a dose-dependent manner, with $50 \%$ inhibitory concentration (IC50) of $12.8 \pm 0.05 \mu \mathrm{g} / \mathrm{mL}$ at $24 \mathrm{~h}$. It induced signs of apoptotic cells, including shrinkage, pyknosis and karyorrhetic nuclei and DNA fragmentation on agarose gel electrophoresis. Moreover, by quantitative real-time PCR, scabraside D effectively decreased Bcl-2 while increasing Bax and Caspase-3 gene expression levels suggesting that the scabraside D could induce apoptosis in HuCCA cells. In vivo study demonstrated that scabraside $D(1 \mathrm{mg} / \mathrm{kg} / \mathrm{day}$, i.p. for 21 days) significantly reduced growth of the HuCCA xenografts without adverse effects on the nude mice. Conclusively, scabraside D induced apoptosis in HuCCA cells and reduced the growth of HuCCA xenographs model. Therefore, scabraside D may have potential as a new therapeutic agent for cholangiocarcinoma.
\end{abstract}

Keywords: Scabraside D - Holothuria scabra - cholangiocarcinoma - apoptosis - sea cucumber extract

Asian Pac J Cancer Prev, 17 (2), 511-517

\section{Introduction}

Cholangiocarcinoma (CCA), is an incurable cancer of the biliary epithelium, and is an important public health problem in many Asian countries (Sripa and Pairojkul, 2008; Shin et al., 2010; Sripa et al., 2011). High prevalence is found in northeast Thailand, where people eat raw freshwater fish infested with Opisthorchis viverrini, the parasitic platyhelminth associated with CCA (Haswell-Elkins et al., 1994). Among the treatment regime of CCA is chemotherapy by 5 -fluorouracil (5-FU), which however is rather ineffective (Hejna et al., 1998). The combined treatment of CCA with chemotherapy and radiotherapy causes severe adverse effects without significantly improving the prognosis of a patient (Sirica, 2005). Therefore, for this and other types of incurable cancer, alternative treatments without adverse effects have been widely sought after. Various extracts from natural products, especially from marine plants and animals, appear promising (Adrain, 2007; Rajasekaran et al., 2008).

Sea cucumber, as one of marine echinoderms, is competent source for novel types of biologically active substances with medical utilization. Holothuria scabra is widely distributed in the Atlantic and Pacific oceans, and is considered a costly gourmet dish in Asian cuisine, and traditional Chinese medicine uses it in tonics and delicacies (Kerr and Chen, 1995). Extracts from sea cucumbers have been reported as anti-cancer agents. Many species of sea cucumber produce triterpene glycosides, a group of saponin, which are poisonous for other organisms and presumably function as a chemical defense against predation (Caulier et al., 2011; Bahrami et al., 2014). This group of substances shows various biological activities, including antifungal, cytotoxic, hemolytic, cytostatic and immunomodulatory effects (Kitagaw et al., 1989; Stonix et al., 1999; Chludil et al., 2002). The sea cucumber $H$. scabra produces a type of sulfated triterpene glycosides called scabraside D, which inhibits the proliferation of

${ }^{1}$ Department of Anatomy, ${ }^{2}$ Center of Excellence for Shrimp Molecular Biology and Biotechnology (Centex Shrimp), ${ }^{6}$ Aquatic Animal Biotechnology Research Center, Prince of Songkhla University Surat Thani Campus, ${ }^{3}$ Preclinic and Applied Animal Science, ${ }^{5}$ Center for Veterinary Diagnosis, Faculty of Veterinary Science, ${ }^{4}$ Nakhonsawan Campus, Mahidol University, Bangkok, Thailand * For correspondence: wboonsirm@yahoo.com 
mouse leukemic cells and various kinds of human cancer cells including lung, gastric, colorectal and breast cancer cells (Han et al., 2012). The mechanism of action of scabraside D on the inhibition of cancer growth is still unknown. However, effect of scabraside D on human cholangiocarcinoma cells has not previously been determined. In this study, we investigated the effect of scabraside D on human cholangiocarcinoma (HuCCA) cell viability, migration, and apoptosis in vitro and in vivo on tumor growth in xenograft models. To our knowledge, this is the first report of scabraside D on the inhibition of HuCCA cell growth with the studies on mechanisms of its effect, as well as a corresponding study on an in vivo inhibition of HuCCA xenographs in animal model.

\section{Materials and Methods}

\section{Cell lines and cell culture}

HuCCA cell line CL6 kindly provided by Associate Professor Dr. Adisak Wongkajornsilp, the Department of Pharmacology, Faculty of Medicine Siriraj Hospital, Mahidol University. It was used both in vitro and as tumor xenograft in vivo. The cells were cultured in DMEM medium, supplemented with penicillin (100 IU/mL), streptomycin $(100 \mu \mathrm{g} / \mathrm{mL})$ and $15 \%$ fetal bovine serum (FBS). They were maintained at $37^{\circ} \mathrm{C}$ in an incubator with a humidified $95 \%$ and $5 \%(\mathrm{v} / \mathrm{v})$ mixture of air $\mathrm{CO}_{2}$.

\section{Isolation and purification of scabraside D}

Live specimens of H. scabra were caught from Andaman Sea, Krabi Province, southern Thailand. Air-dried and finely powdered body walls ( $3 \mathrm{~kg}$, dried weight) of sea cucumber H.scabra were percolated with $2.0 \mathrm{~L}$ of $70 \%$ ethanol for $48 \mathrm{~h}$ twice at room temperature; the ethanol fractions were combined and evapolated in a vacuum chamber to give the crude ethanol extract, which weighed $147.83 \mathrm{~g}$. The extract was dissolved in water and the solution was extracted with n-butanol; the organic fraction was evaporated in a vacuum chamber to yield the butanol fraction, which weighed $6.37 \mathrm{~g}$. The butanol fraction was separated by column chromatography on silica gel $\left(\mathrm{SiO}_{2}, 200 \mathrm{~g}\right)$, eluting with $10 \mathrm{~L}$ of methanol in dichlorometane in series of concentrations from 0 to $100 \%$. The fraction (100 mL each) was combined on the basis of their thin layer chromatography (TLC) behavior to give 10 fractions. The fractions were purified by column chromatography using a Sephadex LH-20 column, eluted with $100 \%$ methanol. The purified scabraside D (10.24 mg) in the form of a white power, was validated by ${ }^{1} \mathrm{H}$ and ${ }^{13} \mathrm{C}$ NMR spectrum. The chemical structure of scabraside D is shown in figure 1 . The substance was dissolved in dimethysulfoxide (DMSO) and diluted to required concentrations before use, with the concentration of DMSO was kept below $0.1 \%$ in the treatment group.

\section{Cell viability assay}

The cell viability was determined using 3-(4,5-dimethylthiazol-2-yl)-2,5-diphenyltetrazolium bromide (MTT) (Sigma-Aldrich Co., St. Louis, MO, USA). The MTT assay is based on the ability of succinate dehydrogenase in mitochrondria that separates yellow tetrazolium salt into purple insoluble formazan products (Mosmann, 1983). Briefly, HuCCA cells were seeded in 96-well plates at a density $1 \times 10^{4}$ cells/well. After $24 \mathrm{~h}$, the cells were treated for 24 and $48 \mathrm{~h}$ with scabraside D at concentrations from 6.25 to $100 \mu \mathrm{g} / \mathrm{ml}$, or with 5-FU at similar concentrations as a positive control. In the negative control group, the cells were treated with $0.1 \%$ DMSO. After removing the medium, the HuCCA cells were subjected to MTT solution for $4 \mathrm{~h}$ to assess their mitochrondrial activity (Tada et al., 1986). Absorbance was measured at $490 \mathrm{~nm}$ using microplate reader (BioRad, Hercules, CA). Averaged values were derived from at least three independent experiments, and are presented as percentages of cell viability, which is estimated as the ratio of mean absorbance for the treatment and for the negative control group.

\section{Cell migration assay}

The cell migraton assay was modified from that of Liang and colleagues (Liang et al., 2007). Briefly, HuCCA cells were seeded in 6-well plates at a density $1 \times 10$ cells/ well and incubated at $37^{\circ} \mathrm{C}$ overnight. The culture medium was aspirated and then scratch wound was made through the confluent monolayer with a plastic sterile pipette tip. This was followed immediately by addition of various concentrations of scabraside $\mathrm{D}(6.25-100 \mu \mathrm{g} / \mathrm{mL})$ into the well plates, which were photographed at $0,3,6$ and $24 \mathrm{~h}$ after scratching. The advance of cell migration to close the wound, with scabraside D treatment or in control plates, was observed under a phase-contrast microscope.

\section{Morphological examinations}

In order to observe the nuclear characteristics of HuCCA cells after scabraside D treatment, nuclear staining was performed using Hoechst 33342 (Sigma-Aldrich Co., St. Louis, MO, USA). The HuCCA cells $5 \times 10^{5}$ cells/ $\mathrm{ml}$ were grown on cover slips placed in 6-well plates overnight, then treated with scabraside D (6.25 to 100 $\mu \mathrm{g} / \mathrm{mL}$ ) and control for $24 \mathrm{~h}$. After $24 \mathrm{~h}$, the cells were washed twice with cold phosphate-buffered saline (PBS), and fixed with cold methanol and acetic acid (3/1, v/v) at $4^{\circ} \mathrm{C}$ overnight. After that, the cells were stained with Hoechst 33342 for $30 \mathrm{~min}$ in the dark, washed with PBS, mounted in a mounting medium ( $80 \%$ glycerol in PBS) and observed under a Confocal Laser Scaning microscope (Olympus FV 1000). In addition, after treatment the cells were processed for Epon resin embedding and semi-thin sections. The cells were fixed with in $4.5 \%$ glutaraldehyde in phosphate buffer (PB) for $1 \mathrm{~h}$ and post-fixed in $1 \%$ osmium tetroxide in $0.2 \mathrm{M} \mathrm{PB}$ for $1 \mathrm{~h}$ at $4^{\circ} \mathrm{C}$. After washing, the cells were dehydrated in a series of ethanol (from 30 to $100 \%$ ) changes of acetone. After that, the cells were incubated in acetone/Epon resin 812 at 1:1 for overnight. This was followed by embedding in $100 \%$ Epon resin 812 for $4 \mathrm{~h}$, and incubated at $60^{\circ} \mathrm{C}$ for 3 days. Semithin sections were cut, the stained with toluidine blue and examined under a light microscope (LM).

\section{DNA fragmentation}

The HuCCA cells $\left(1 \times 10^{6}\right.$ cells $)$ were grown in 6-well plates overnight, followed by treatments with various

512 Asian Pacific Journal of Cancer Prevention, Vol 17, 2016 concentrations of scabraside D (6.25 to $100 \mu \mathrm{g} / \mathrm{ml})$ for 24 
Scabraside D from Holothuria scabra Induces Apoptosis and Inhibits Growth of Human Cholangiocarcinomas in Mice

h. After that, the cells were harvested washed twice with ice-cold PBS, resuspend in Tris buffered saline-EDTA (10 $\mathrm{mM}$ Tris- $\mathrm{HCl}$ at $\mathrm{pH} 7.6,140 \mathrm{mM} \mathrm{NaCl}$, and $1 \mathrm{mM}$ EDTA) and lysed in the extraction buffer $(0.1 \mathrm{M} \mathrm{NaCl}, 10 \mathrm{mM}$ Tris-HCl, 25 mM EDTA, pH 8.0; $100 \mu \mathrm{L}$ per $1 \times 10^{6}$ cells). The lysates were incubated with $25 \mu \mathrm{L}$ of $10 \%$ sodium dodecyl sulfate (SDS) $(25 \mu \mathrm{L}, 10 \%)$ and $5 \mu$ l of proteinase $\mathrm{K}(20 \mathrm{mg} / \mathrm{mL})$ for $1 \mathrm{~h}$ at $50^{\circ} \mathrm{C}$. One $\mu \mathrm{L}$ of RNase $(1 \mathrm{mg} /$ $\mathrm{mL}$ ) was added and incubated for $1 \mathrm{~h}$ at $37^{\circ} \mathrm{C}$. Then, 100 $\mu 1$ of $5 \mathrm{M} \mathrm{NaCl}$ was added and DNA was extracted twice with equal volumes of phenol:chloroform:isoamylalcohol $(25: 24: 1)$ solution. The extracted DNA was precipitated by adding $500 \mu \mathrm{L}$ of cold absolute ethanol at $1 \mathrm{~h}$. Then, it was centrifuged at $12,000 \times \mathrm{g}$ for $10 \mathrm{~min}$ at $4^{\circ} \mathrm{C}$ and rinsed with $500 \mu \mathrm{L}$ of $70 \%$ ethanol. This was followed by $12,000 \times$ $\mathrm{g}$ centrifugation for $10 \mathrm{~min}$ at $4^{\circ} \mathrm{C}$ and the DNA pellets were allowed to dry for $20 \mathrm{~min}$ at room temperature. The DNA pellets were then dissolved in TE buffer $(10 \mathrm{mM}$ Tris, 1 mM EDTA, pH 8.0); the solution was loaded on $2 \%$ agarose gel, separated by electrophoresis $(110 \mathrm{~V}, 35$ min) and visualized by ethidium bromide staining.

\section{RNA extraction}

HuCCA cells were collected at $24 \mathrm{~h}$ after treatment and washed twice with PBS. Total RNA was extracted using $1 \mathrm{~mL}$ of TRIzol ${ }^{\circledR}$ Reagent (Invitrogen, Paisley, UK). The sample was added to one-fifth volume of chloroform $(0.2 \mathrm{~mL})$, shaken for $15 \mathrm{~s}$, incubated for $5 \mathrm{~min}$ at room temperature. The mixture was centrifuged at $15,000 \times \mathrm{g}$ for $10 \mathrm{~min}$ at $4^{\circ} \mathrm{C}$, and the aqueous phase was transferred to a new tube. Isopropanol $(0.5 \mathrm{~mL})$ was added into the solution, which was kept at room temperature for $15 \mathrm{~min}$ to precipitate the RNA. The sample was centrifuged at $15,000 \times \mathrm{g}$ for $10 \mathrm{~min}$ at $4^{\circ} \mathrm{C}$ and the supernatant was discarded. The pellet was washed twice with $1 \mathrm{~mL}$ of $75 \%$ ethanol, centrifuged at $7,500 \times \mathrm{g}$ for $10 \mathrm{~min}$ at $4^{\circ} \mathrm{C}$, and dried for $10 \mathrm{~min}$ at $55^{\circ} \mathrm{C}$. The dried pellets were re-suspended in de-ionized distilled water $(30 \mu \mathrm{L})$ and stored at $-80^{\circ} \mathrm{C}$ until use. The total RNA was converted to cDNA using the SuperScript ${ }^{\mathrm{TM}}$ III reverse transcription kit following the instruction manual (Invitrogen, Paisley, UK).

\section{Quantitative real-time PCR}

Quantitative real-time PCR was performed to determine the expression levels of $\mathrm{BCl}-2$, Bax, caspase-3 and GAPDH. A $20 \mu \mathrm{L} \mathrm{PCR}$ reaction mixture contained $2 \mu \mathrm{L}$ of first-strand cDNA of each primer and $18 \mu \mathrm{L}$ of KAPA SYBR ${ }^{\circledR}$ FAST qPCR kit Master Mix (2x) (KAPA Biosystems, Woburn, MA), and was processed in an ABI 7500 Real-Time PCR system (Appiled Biosystems, Foster City, CA). The specific primers were designed according to the full cDNA sequences of Bax (GeneBank accession no. AY217036), Bcl-2 (GeneBank accession no. BC027258), caspase-3 (GeneBank accession no. NM_004346), and GAPDH (GeneBank accession no. NM_002046) using Primer Blast Program (Ye et al., 2012). The following specific primers (Pacific Science Co., Ltd., Thailand) were used: Bax, 5'-ATGCCCGTTCATCTCAGTCC-3' (sense) and 5'-GAAGTGTGTCCCGAAGGAGG-3' ( antisense) 400 bp product; Bcl-2,
5'-TGGGAGAACGGGGTACGATA-3' (sense) and 5'-CATGACCCCACCGAACTCAA-3' (antisense) $460 \mathrm{bp}$ product; caspase 3,5'-GTTGGCGTCGCCTTGAAATC-3' (sense) and 5'-TGAGGTTTGCTGCATCGACA-3' (antisense) 349 bp product; and GAPDH, 5'-CTCCTGTTCGACAGTCAGCC-3' (sense) and 5'-TTCCCGTTCTCAGCCTTGAC-3' (antisense) 262 bp product. The PCR conditions were as follows: the amplification primary incubation at $95^{\circ} \mathrm{C}$ for $10 \mathrm{~min}$, followed by 40 cycles of denaturation at $95^{\circ} \mathrm{C}$ for 10 min, annealing at $60^{\circ} \mathrm{C}$ for $1 \mathrm{~min}$, and extension at $60^{\circ} \mathrm{C}$ for $1 \mathrm{~min}$. The sequences of these PCR products were obtained by direct sequencing. Each amplicon was cloned into PGEM®-t Vector (Promega, Madison, WI, USA) in order to create standard curves for target cDNA. The mRNA levels were reported as ratios of the copy numbers of target cDNAs to GAPDH cDNA.

\section{Effect on xenograft model}

Six-week-old female BALB/cMlac-nu mice were purchased from the National Laboratory Animal Center, Salaya District, Nakorn Prathom Province, Thailand. The experimental protocol was conducted by National Research Council (NRC), Thailand, and was approved by the Faculty of Veterinary Science, Mahidol University. HuCCA cells, $2.5 \times 10^{6}$ in number, were used for xenograting all mice. The cells were injected subcutaneously into the right flanks of 10 nude mice. At day 14 after the injection, the tumor size reached approximately $50 \mathrm{~mm} 3$. At that time, the mice were randomly divided into two groups, five each, and treated with scabraside D (1 mg/kg/day) or vehicle control [100 $\mu \mathrm{L}$ normal saline solution (NSS)] by intraperitoneal (i.p) injections. The body weights of the mice were recorded every 7 days, and tumor size was recorded every 3 days. The tumor size was measured in two dimensions (maximum longitudinal and transverse diameters) using a caliper and the volume estimated as: (length) $\times$ (width) $2 / 2$ (Plengsuriyakarn et al., 2012). After 21 days of treatment, all the mice were euthanized and the tumors were dissected and weighed.

\section{Statistical analysis}

Data were expressed as mean \pm SD from three or more independent experiments. Statistical significance was accessed by analysis of variance (ANOVA) followed by Bonferroni post-test in GraphPad Prism program version 5 (GgraphPad software, San Diego, CA). Difference with p-values $<0.05$ was considered statistically significant.

\section{Results}

\section{Inhibition of $\mathrm{HuCCA}$ cell viability and migration}

HuCCA cell viability decreased in a dose-dependent manner with scabraside D treatments, as observed at 24 and $48 \mathrm{~h}$, and with 5-FU treatments for observation at $48 \mathrm{~h}$ (Figure 2A). Statistically siginificant inhibition was detected with doses from 12.5 to $100 \mu \mathrm{g} / \mathrm{ml}$ for both scabraside D and 5-FU treatments, compared to the respective control groups $(0 \mu \mathrm{g} / \mathrm{mL}$ dose $)$. There was no statistically significant difference in inhibition between scabraside D (for $24 \mathrm{~h}$ and $48 \mathrm{~h}$ treatments) 


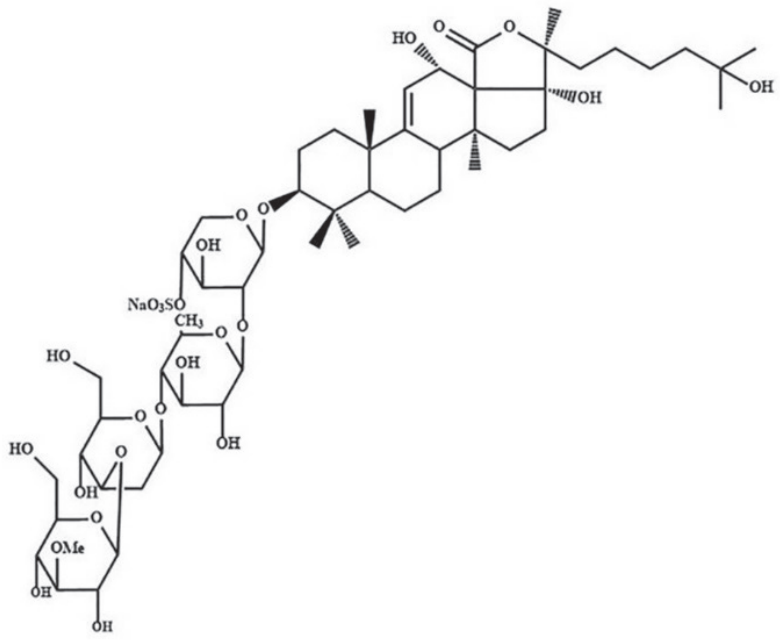

Figure 1. The Chemical Structure of Scabraside D

A

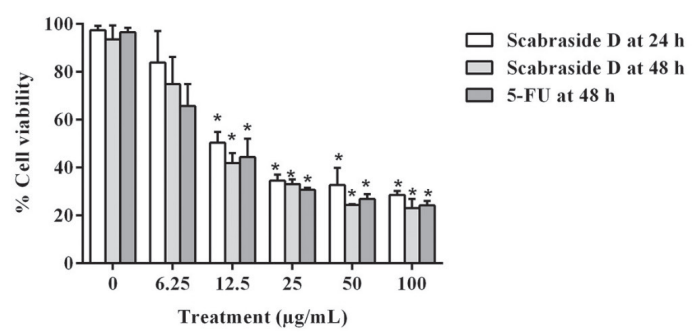

B
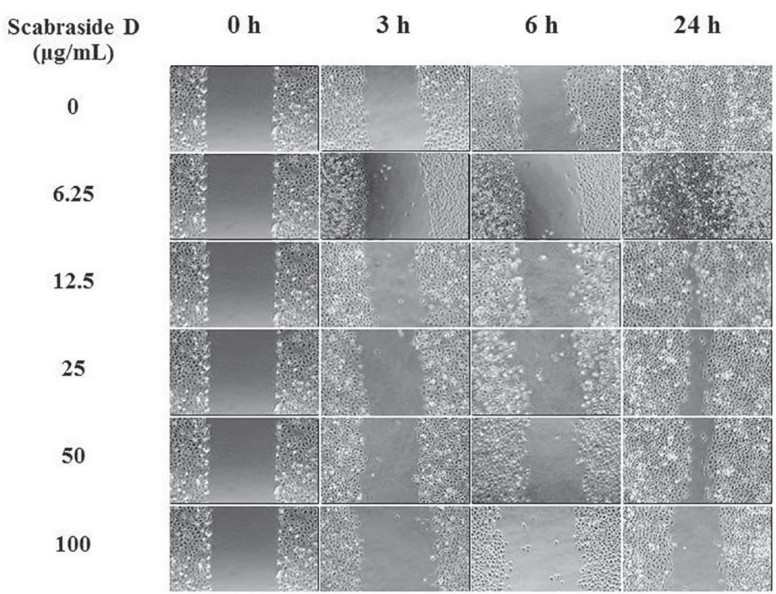

Figure 2. Inhibition of HuCCA Cell Viability by

Scabraside D and 5-FU. (A), and HuCCA cell migration by scabraside D (B). The * indicates statistical significance with $\mathrm{p}$ $<0.05$, compared to the viability in the respective control. No statistically significant difference in $\%$ cell viability was detected between the $24 \mathrm{~h}$ and $48 \mathrm{~h}$ treatments with scabraside D and the $48 \mathrm{~h}$ treatment with 5-FU, at equal concentrations

and 5-FU treatment ( $48 \mathrm{~h}$ treatment), on comparing equal concentrations. The averaged $50 \%$ inhibitory concentration (IC50) value of scabraside D on HuCCA cell growth was approximately $12.80 \pm 0.05 \mu \mathrm{g} / \mathrm{ml}$. In addition, the effect of scabraside D on HuCCA cell viability was compared with the treatment with 5-FU. The result showed that scabraside D could decrease the cell viability as effectively as 5-FU at the same concentration. The inhibition of HuCCA cell migration

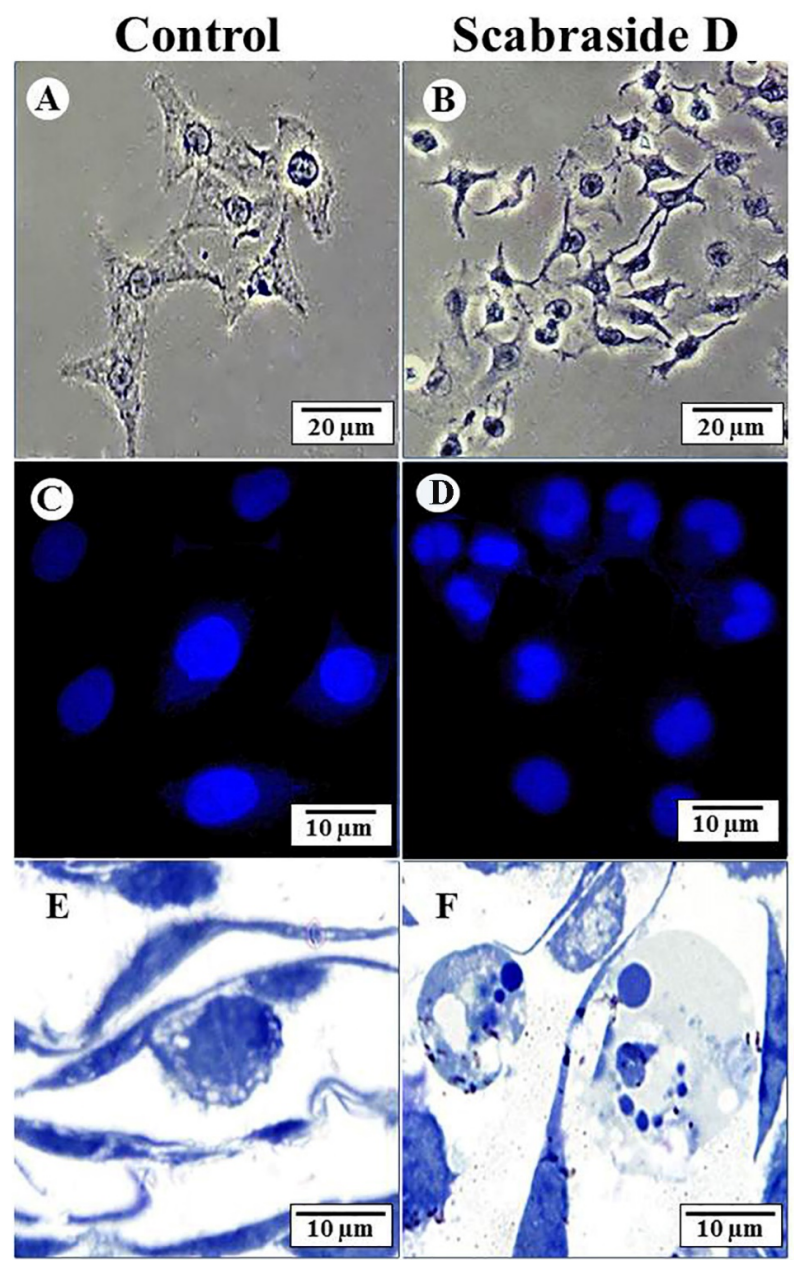

Figure 3. Microscopic Morphology of HuCCA Cells. Control (A, C and E) and in $24 \mathrm{~h}$ scabraside D-treated group (B, D and F). The scabraside D-treated cells displayed cellular shrinkage under a phase contrast microscope (B), fragmented nuclei by Hoechst 33342 staining (D) and karryorrhetic nuclei in a semi-thin section $(\mathrm{F})$

in a plate culture is shown in figure $2 \mathrm{~B}$. In the control group (no treatment), after the layer of the cultured cells was scratched, the dividing cells along the sides of the scratch migrated into the scratch area and almost filled it up within $24 \mathrm{~h}$. Under scabraside D treatment, the rate by which the migratory cells filled the scratch was slower than in the control group, and clearly slowed down with increasing doses of scabraside D. The result indicates that the substance retarded HuCCA cell migration in a dosedependent manner.

\section{Induction of apoptosis}

In comparison to the control group (Fig. 3A), the scabraside D-treated HuCCA cells showed higher degrees of cell shrinkage under a phase contrast microscope (Figure 3B). The treated cells also showed some degree of nuclear fragmentation and condensation under Hoechst fluorescent staining (Figure 3D, compared to Figure 3C), and revealed nuclear shrinkage with pyknosis and karryorrhexis in semi-thin sections (Figure 3F, comopared to Figure 3E). Furthermore, by agarose gel electrophoresis, the DNA extracts from the scabraside D-treated cells displayed cleaved DNA fragments observed as DNA ladder on 


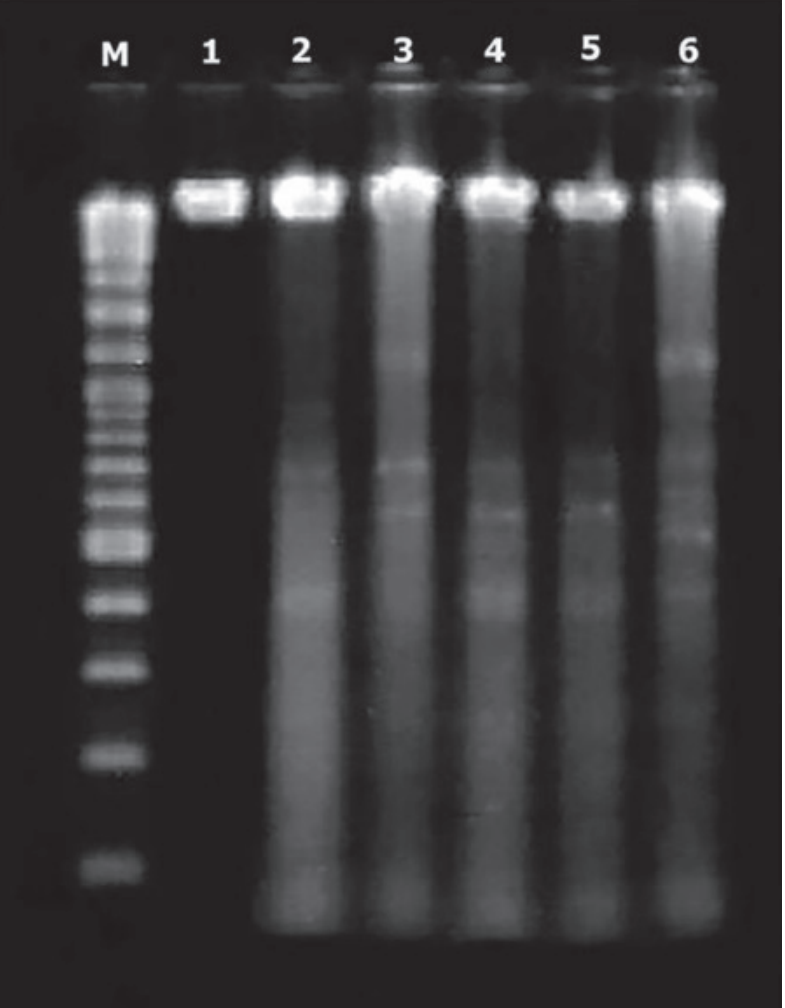

Figure 4. DNA Fragmentation of HuCCA Cells after Treatment with Various Concentrations of Scabraside D. Analyzed by agarose gel electrophoresis: Lanes 1-6, scabraside D at concentrations of $0,6.25,12.5,25,50$ and 100 $\mu \mathrm{g} / \mathrm{mL}$; lane $\mathrm{M}$ is for DNA markers

the gel (Figure 4, lane 2-6), whereas the untreated cells showed no ladder on the gel (Figure 4, lane 1). The result suggests that scabraside D caused internucleosomal DNA fragmentation. Thus, these morphological alterations and evidence of DNA fragmentation on gel electrophoresis suggest that apoptotic processes were on-going in HuCCA cells treated by scabraside D.

\section{Effects on apoptosis-related genes}

The expression levels of Bcl-2, Bax and caspase-3 in the scabraside D-treated cells were determined by Quantitative real-time PCR analysis. In comparison to the control group, scabraside D treatment increased Bax but decreased Bcl-2 levels in HuCCA cells in a dosedependent manner (Figure 5A-B). These resulted in an increasing ratio of $\mathrm{Bax} / \mathrm{Bcl}-2 \mathrm{mRNA}$ in the scabraside D-treated group in a dose-dependent manner as well (Figure 5C). The expression of caspase-3 increased in the scabraside D-treated group, more or less in a dosedependent manner (Figure 5D). In all the values obtained, significant differences to the untreated group $(\mathrm{p}<0.05)$ were observed when the dose of scabraside D was at 25 , 50 and $100 \mu \mathrm{g} / \mathrm{mL}$. These changes in gene expressions induced by scabraside D confirm the apoptosis-induced action as a mechanism suppressing the viability and migration of HuCCA cells.

\section{Inhibition of tumor growth in xenograft model}

To confirm the pharmacological relevance of the in vitro data, effects of the scabraside D on human CCA
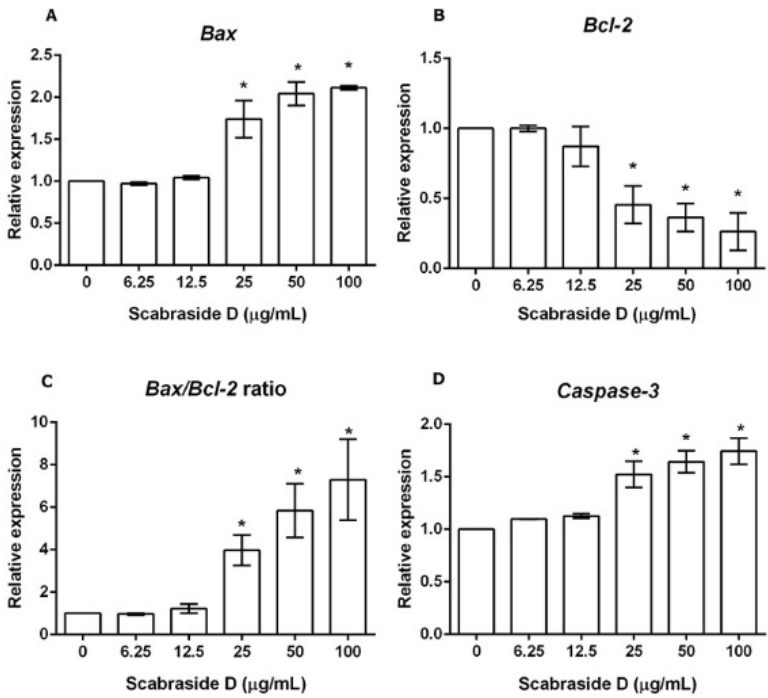

Figure 5. Gene Expression Results for Bax. (A), $\mathrm{Bcl}-2$ (B), Bax/Bcl-2 ratio (C), and caspase-3 (D) in HuCCA cells following scabraside $D$ treatment at various concentrations. The values are mean $\pm \mathrm{SD}$ relative to the control values, and normalized based on GAPDH $(n=3)$. The $*$ indicates statistical significance at $\mathrm{p}<0.05$ in comparison to control $(0 \mu \mathrm{g} / \mathrm{ml})$
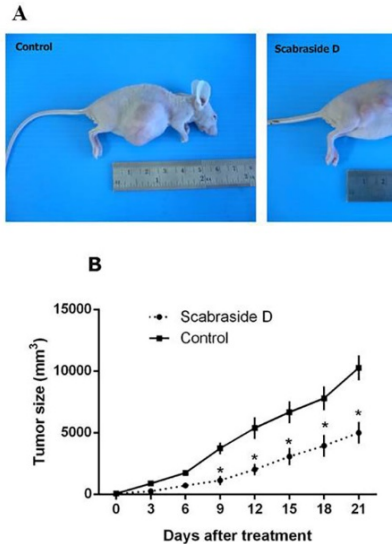

Days after treatment

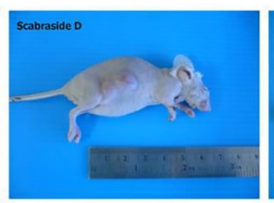

C

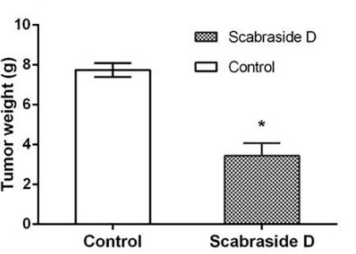

Figure 6. Nude mice with HuCCA tumors, and the gross xenograft morphologies from the control and scabraside D-treated (1 $\mathrm{mg} / \mathrm{kg} / \mathrm{day}$ intraperitoneal) mice. (A), the time profile of tumor size from the first day of scabraside D or normal saline injections, which showed statistical significance between the two groups from day 3 onwards (B), and a histogram of tumor weights at day 21 of treatement $(C)$. Values are mean $\pm \operatorname{SD}(n=5)$. The * indicates statistical significance at $\mathrm{p}<0.05$ in comparison to control

tumor growth were investigated in xenograft model. The anti-cancer activity of scabraside $\mathrm{D}$ was evaluated in vivo in BALB/cMlac-nu mice inoculated with HuCCA cells. The growth of the HuCCA tumor xenografts was recorded every third day for 21 contiguous days after intraperitoneal injection of scabraside D at $1 \mathrm{mg} / \mathrm{kg} / \mathrm{day}$. Figure 6 A shows a representative HuCCA tumor from a xenograft model. The sizes of HuCCA xenografts in the animals injected with scabraside D were significantly smaller than in the control group from day 9 of the treatment onwards, tumor size with treatment reduced $41.12 \%$ of that of the control 
group (Figure 6B) Moreover, at the end of experiment, the average tumor weight of the treatment group was less than that of the control group (Figure 6C). The mice exhibited no observable signs of scabraside $\mathrm{D}$ toxicity during the treatment and, at necropsy, no gross abnormalities were detected in any organs of the mice. This result suggested that scabraside D at the dose provided inhibited HuCCA tumor growth in xenograft models, without adverse effects to the animals.

\section{Discussion}

From this study, it is clear that scabraside D, an extract from the sea cucumber H. scabra inhibited the growth of human cholangiocarcinoma cells by induction of apoptosis. Scabraside D has been shown in vitro to have anti-proliferation property against five cancer cell lines including, mouse leukemic cells (P-388), lung human cancer cell (A-549), gastric cancer cell (MKN-28), human colorectal cancer cell (HCT-116) and human breast cancer cell (MCF-7) (Han et al., 2012). However, that study did not suggest a mechanism of the inhibition.

The current study demonstrated the decrease in HuCCA cell viability and migration in response to the scabraside D. Our data showed that the scabraside D could decrease cell viability on HuCCA cells comparable to similar doses of 5-FU. This well-known chemotherapeutic agent 5-FU induces cellular necrosis in tumor (Chen et al., 2014), whereas scabraside D induced apoptosis. The growth inhibitory effect of scabraside D in HuCCA cells was likely modulated via apoptosis as the cells exhibited typical characteristics of apoptosis, i.e., cell shrinkage, chromatin condensation, irregularly fragmented pyknotic and karrhetic nuclei, and DNA ladder formation. Separating of DNA at the inter-nucleosomal linked sites result in DNA fragments has been indicated apoptosis (Mark, 1992). Apparently, the increase of apoptotic cells after treatment of scabraside D caused the decrease in HuCCA cell viability and migration. Moreover, the expression of apoptosis-related genes in the scabraside $\mathrm{D}$ treated cells showed up-regulation of caspase- 3 gene, pro-apototic Bax gene and down-regulation of $\mathrm{Bcl}-2$, leading to an enhance in $\mathrm{Bax} / \mathrm{Bcl}-2$ ratio. The $\mathrm{Bcl}-2$ family of apoptosis regulators comprises anti-apoptotic genes (Bcl-2, Mcl-1, Bcl-xL) and pro-apoptotic genes (Bax, Bak, Bad) (Li et al., 2008). The Bcl-2 family plays a critical role in apoptotic pathway via the mitochondrial pathway (Green and Reed, 1998; Oltersdorf et al., 2005). The mitochondrial pathway is crucial induction of disruption in mitochondria through the alteration of $\mathrm{Bax} / \mathrm{Bcl}-2$ ratio. Increasing Bax stimulates the intrincsic apoptotic pathway by inducing permeabilization of the outer mitochondrial membrane, leading to a release of cytochrome $\mathrm{C}$ into the cytoplasm and subsequently caspase up-regulation, while Bcl-2 is down-regulated (Li et al., 2008; Tilli et al., 2002; Camins et al., 2008). The release of cytochrome C from mitochondria directly stimulates caspase-9-induced caspase-3 activation via formation of the apoptosome complex. The gene caspase-3 plays a major role in alterating the nuclear DNA in apoptotic cells. Hence, the stimulated caspase- 3 is able dividing many cellular substrates result in DNA fragmentation (Woo et al., 1998; Zheng et al., 1998; Tilli et al., 2002; Bras et al., 2005). As the growth and development of cancer are relating to unbalanced cell growth and apoptosis (Piotr et al., 2004), thus, one of the anti-cancer mechanisms is to induce apoptosis to the cancer cells.

Another anti-cancer agent with similar chemistry and similar mechanism of action is fomitoside-K, a lanostane triterpene glycoside isolated from the mushroom Fomitopsis nigra. This substance has been found to induce apoptosis of human oral squamous cell carcinoma via down-regulation of Bcl-2 and up-regulation of Bax, which leads to the activation of caspase-3 (Bhattarai et al., 2012). In the current study, scabraside D down-regulated Bcl-2 while up-regulating Bax, thus increasing Bax/Bcl-2 ratio and causing apoptosis of HuCCA cells.

This in vitro study was corroborated by an in vivo study, in which scabraside D suppressed the growth of HuCCA xenograft in nude mice, the tumor size and tumor weight of treatment group was smaller than that of the control group. In addition, the animals survived throughout the cause of the experiment without apparent abnormalities at necropsy, or any other visible signs of toxicity. This result suggested the absence of untoward side effects of scabraside D. Although we only demostrated apoptosis as a mechanism by scabraside $\mathrm{D}$, other mechanisms of action inhibiting the viability, migration and growth of the cancer cells may exist. For instance, inhibition of neoangiogenesis and preventing in this way the vascularization of a tumor would slow down tumor growth and metastasis. It has been shown that a sulfated saponin isolated from the sea cucumber Pentacta quadrangularis inhibit neoangiogenesis in the cholioallantoic membrane of chicken (Tian et al., 2005). As the CCA is highly malignant, it remains to find out whether scabraside D could also prevent its metastasis. The potential application of scabraside D against other cancer types also awaits further research.

In conclusion, our study showed that the scabraside D could induce HuCCA cell apoptosis, which likely caused the decrease in HuCCA cell viability and migration. Furthermore, we demonstrated that the scabraside D could reduce HuCCA tumor growth in the xenograft models. Based on these results, the scabraside $\mathrm{D}$ could be a promising candidate for the cholangiocarcinoma therapy.

\section{Acknowledgements}

This research was financially supported by the Royal Golden Jubilee Ph.D. Program (RGJPHD), PHD/0012/2552.

\section{References}

Adrain TE (2007). Novel marine-derived anti-cancer agents. Curr Pharm Des, 13, 3417-26.

Bahrami Y, Zhang W, Chataway T, et al (2014). Structural elucidation of novel saponins in the sea cucumber Holothuria lessoni. Mar Drugs, 12, 4439-73.

Bhattarai G, Lee YH, Lee IK, et al (2012). Fomitoside-K from Fomitopsis nigra induces apoptosis of human oral squamous 
Scabraside D from Holothuria scabra Induces Apoptosis and Inhibits Growth of Human Cholangiocarcinomas in Mice

cell carcinomas (YD-10B) via mitochondrial signaling. Biol Pharma Bull, 35, 1711-19.

Bras M, Queenan B, Susin SA (2005). Programmed cell death via mitochondria: different modes of dying. Biochem (Mosc), 70, 231-39.

Camins A, Pallas M, Silvestre JS (2008) Apoptotic mechanisms involved in Neurodegenerative diseases: experimental and therapeutic approaches. Method Find Exp Clin Pharmacol, 30, 43-65.

Caulier G, Dyck SV, Gerbaux P, et al (2011). Review of saponin diversity in sea cucumbers belonging to the family Holothuriidae. SPC Beche-de-mer Inf Bull, 31, 48-54.

Chen X, Li Y, Lin Q, et al (2014). Tea polyphenols induced apoptosis of breast cancer cells by suppressing the expression of Survivin. Sci Rep, 4, 1-5.

Chludil HD, Muniain CC, Seldes AM, et al (2002). Cytotoxic and antifungal triterpene glycosides from the Patagonian sea cucumber Hemoiedema spectabilis. J Nat Prod, 65, 860-65.

Green DR, Reed JC (1998). Mitochondria and apoptosis. Science, 281, 1309-12.

Han H, Li L, Yi YH, et al (2012). Triterpene glycosides from sea cucumber Holothuria scabra with cytotoxic activity. Chin Herb Med, 4, 183-88.

Haswell-Elkins MR, Mairiang E, Mairiang P, et al (1994). Cross-sectional study of opisthorchis viverrini infection and cholangiocarcinoma in communities within a high-risk area in northeast Thailand. Int J Cancer, 59, 505-9.

Hejna M, Pruckmayer M, Raderer M (1998). The role of chemotherapy and radiation in the management of biliary cancer: a review of the literature. Eur J Cancer, 34, 977-86.

Kerr RG, Chen Z (1995). In vivo and in vitro biosynthesis of saponins in sea cucumbers. J Nat Prod, 58, 172-76.

Kitagawa I, Kobayashi M, Hori M, et al (1989). Marine natural products. XVIII. Four lanostane-type triterpene oligoglycosides, bivittosides A, B, C, and D, from the Okinawan sea cucumber Bohadschia bivittata Mitsukuri. Chem Pharma Bull, 37, 61-7.

Li X, Roginsky AB, Ding XZ, et al (2008). Review of the apoptosis pathways in pancreatic cancer and the antiapoptotic effect of the novel sea cucumber compound, Frondoside A. Ann N Y Acad Sci, 1138, 181-98.

Liang CC, Park AY, Guan JL (2007). In vitro scratch assay: a convenient and inexpensive method for analysis of cell migration in vitro. Nat Protc, 2, 329-33.

Mark MC (1992). Abiochemical hallmark of apoptosis: internucleosomal degradation of the genome. Canc Metastasis Rev, 11, 105-19.

Mosmann T (1983). Rapid colorimetric assay for cellular growth and survival: application to proliferation and cytotoxicity assays. J Immunol Methods, 65, 55-63.

Oltersdorf T, Elmore SW, Shoemaker AR, et al (2005). An inhibitor of Bcl-2 family proteins induces regression of solid tumors. Nature, 435, 677-81.

Piotr D, Dumanska M, Forgacz J, et al (2004). Intensity of apoptosis as related to the expression of metallothionein (MT), caspase-3 (cas-3) and Ki-67 antigen and the survival time of patients with primary colorectal adenocarcinomas. Ocz, Akad Med Bialymst, 49, 5-7.

Plengsuriyakarn T, Viyanant V, Eursitthichai V, et al (2012). Anticancer activities against cholangiocarcinoma, toxicity and pharmacological activities of Thai medicinal plants in animal models. BMC Complement Altern Med, 12, 1-19.

Rajasekaran A, Sivagnanam G, Xavier R (2008). Nutraceuticals as therapeutic agents: a review research. J Pharm Tech, $\mathbf{1}$, $328-40$.

Shin HR, Oh JK, Masuyer E, et al (2010). Epidemiology of cholangiocarcinoma: an update focusing on risk factors.
Cancer Sci, 101, 579-85.

Sirica AE (2005). Cholangiocarcinoma: molecular targeting strategies for chemoprevention and therapy. Hepatol, 41, $5-15$.

Sripa B, Bethony JM, Sithithaworn P, et al (2011). Opisthoriasis and Opisthorchis-associated cholangiocarcinoma in Thailand and Laos. Acta Trop, 120, 158-68.

Sripa B, Pairojkul C (2008). Cholangiocarcinoma: lessons from Thailand. Curr Opin Gastroenterol, 24, 349- 56.

Stonix VA, Kalinin VI, Avilov SA (1999). Toxin from sea cucumbers (Holothuroids): chemical structures, properties, taxonomic distribution, biosynthesis and evolution. $J$ Nat Toxins, 8, 235-48.

Tada H, Shiho O, Kuroshima M, et al (1986). An improved colorimetric assay for interleukin 2. J Immunol Methods, 93, 157-65.

Tian F, Zhang X, Tong Y, et al (2005). PE, a new sulfated saponin from sea cucumber, exhibits anti-angiogenic and anti-tumor activities in vitro and in vivo. Cancer Biol Ther, 4, 874-82.

Tilli CM, Stavast-Koey AJ, Ramaeker FC, et al (2002). Bax expression and growth behavior of basal cell carcinomas. $J$ Cutan Pathol, 29, 79-87.

Woo M, Hakem R, Soengas MS, et al (1998). Essential contribution of caspase-3/CPP32 to apoptosis and its associated nuclear change. Genes Dev, 12, 806-19.

Ye J, Coulouris G, Zaretskaya I, et al (2012). Primer-BLAST: A tool to design target-specific primers for polymerase chain reaction. BMC Bioinformatics, 13, 134.

Zheng TS, Schlosser SF, Dao T, et al (1998). Caspase-3 controls both cytoplasmic and nuclear events associated with Fasmediated apoptosis in vivo. Proc Natl Acad Sci USA, 95, 13618-23. 